\title{
BERAGAM TINDAK PIDANA LAUT DALAM HUKUM PIDANA INDONESIA
}

\author{
Oleh : IWAN SETIAWAN, S.H., M.H. *)
}

\begin{abstract}
Indonesia is a country that has the greatest area of ocean in the world, made up of thousands of islands, both large and small islands island occurrence of disturbance in the territorial waters or marine jurisdictions Indonesia the most important is the disruption cruise passengers and goods. Definition of criminal acts at sea is a criminal offense that could only happen at sea and can not happen on land, distinguished by a general criminal offense that occurred at sea. The criminal acts at sea consists of the Crime of Piracy / Piracy at Sea, Crime Fishing, Crime Valuable Origin Cargo Ship Sinking in Seabed, Environmental Criminal, Crime Sailing, Crime Conservation of Biological Resources and its ecosystem, Follow criminal Customs, Crime Forestry, Crime Immigration, Crime Sand Mining Marine, Crime Abuse region (No Security Clearance), Crime Narcotic Drugs and Psychotropic Substances, Crime Firearms and Explosives, the Crime in the EEZ of Indonesia, criminal Acts of Terrorism, criminal acts at sea that do occur in the region classified as illegal and sea waters in the region that has the character berbada depending on his actions.
\end{abstract}

\section{ABSTRAK}

Indonesia merupakan suatu negara yang memiliki wilayah laut yang paling besar di dunia, terdiri dari ribuan pulau, baik pulau besar maupun pulau kecil Terjadinya gangguan yang terjadi di wilayah perairan atau wilayah yurisdiksi laut Indonesia yang paling utama yaitu terhadap gangguan pelayaran penumpang serta barang. Pengertian tindak pidana di laut adalah tindak pidana yang hanya bisa terjadi di laut saja dan tidak bisa terjadi di darat, dibedakan dengan tindak pidana umum yang terjadi di laut. Tindak pidana di laut terdiri dari Tindak Pidana Perompakan/Pembajakan di Laut, Tindak Pidana Perikanan, Tindak Pidana Benda Berharga Asal Muatan Kapal yang Tenggelam di Dasar Laut, Tindak Pidana Lingkungan Hidup, Tindak Pidana Pelayaran, Tindak Pidana Konservasi Sumber Daya Hayati dan Ekosistimnya, Tindak Pidana Kepabeanan, Tindak Pidana Kehutanan, Tindak Pidana Keimigrasian, Tindak Pidana Penambangan Pasir Laut, Tindak Pidana Pelanggaran wilayah (Tanpa Security Clearance), Tindak Pidana Narkotika dan Psikotropika, Tindak Pidana Senjata Api dan Bahan Peledak, Tindak Pidana di ZEE Indonesia, Tindak Pidana Terorisme. tindak pidana di laut yaitu perbuat melwan hukum terjadi diwilayah laut maupun diwilayah perairan yang memiliki karakter berbada-beda di setiap perbuatannya.

\footnotetext{
*) Dosen Fakultas Hukum Universitas Galuh
} 


\section{PENDAHULUAN}

Indonesia merupakan suatu negara yang memiliki wilayah laut yang paling besar di dunia, terdiri dari ribuan pulau, baik pulau besar maupun pulau kecil Identitas Kelautan Indonesia. Negara Kepulauan Fakta geografis wilayah Indonesia, Negara Kelautan Fakta biofisik, 70\% wilayah adalah laut, Negara Maritim Pengelolaan laut untuk kepentingan bangsa Indonesia total luas laut : 5,8 $(5,9)$ juta $\mathrm{km}^{2}$, Luas laut teritorial: 3,1 juta km2 Luas ZEE Indonesia : 2,7 (2,9) juta $\mathrm{km}^{2}$, Luas daratan : 1,89 juta $\mathrm{km}^{2}$,Panjang garis pantai : $95.181 \mathrm{~km}$, Jumlah pulau: 17.000 (13.466) (Zainal Arifin; 2-3: 2015).

Sebagai negara kepulauan terbesar di dunia dengan keanekaragaman serta kekayaan sumberdaya perairannya. Bukan hal yang mustahil pembangunan kelautan (blue economy) ditempatkan sebagai mainstream pembangunan ekonomi nasional untuk mengembalikan kejayaan Indonesia sebagai negara maritim seperti yang disampaikan oleh Presiden Jokowi ketika terpilih sebagai pemimpin bangsa ini. Beliau merencanakan menjadikan maritim sebagai kekuatan ekonomi masa depan, bahkan akan menjadikan Indonesia sebagai poros maritim dunia. (Yudi N. Ihsan,3:2015).

Potensi geografi dan sumber daya alam laut 17.508 pulau besar dan kecil, Panjang pantai $81.000 \mathrm{Km}^{2}$ Luas wilayah darat 2.027.087 $\mathrm{Km}^{2}$; laut:5,8 $\mathrm{Km}^{2}$ (3.166.163Km² PerNus-PerTer), ZEE $2.500 .000 \mathrm{Km}^{2}$ (sebelum Timtim lepas dari NKRI) Sumber Daya Alam terbaharukan dan tidak terbaharukan melimpah,Terapit oleh Benua Asia dan Australia, berada diantra Samudera Hindia dan Pasifik. (Munsi Lampe,2:2015)

Gambaran potensi ESDM di dasar laut Minyak bumi; Terukur (86,9 bb); Terbukti (9 bb) $=10.36 \%$ Gas bumi: Terukur (384,7 tcf); Terbukti (90 tcf) = 23.39\%Sumber Daya Mineral: timah, kerak dan nodul mangaan, kobal, pasir besi, kromit, zirkon, monasit. (Noor Cahyo D. Aryanto, 7 : 2015). Indonesia Negara Maritim dan/atau Negara Kepulauan :

1) Menurut Deklarasi Djuanda 1957 dan Konvensi Hukum Laut PBB 1982 serta UU Indonesia, Indonesia disebut sebagai Negara Kepulauan, bukan/belum negara maritim

2) Menurut hemat saya, dilndonesia adalahNegara Kepulauan yang mempunya hak-hak tertentu atas kelautan yang sedang menuju menja di Negara Maritim. 
3) Negara Maritim, menurut hemat saya adalah negara yang mampu memanfaatkan laut walaupun dia tidakpunya laut, seperti Singapura, Belanda, dll (HasjimDjalal 2:2015)

Potensi Sumber Daya laut lainnya Hampir 37\% kekayaan biodiversity hayati laut ada di Indonesia,Indonesia memiliki 17,95\% Terumbu karang di dunia, 910 jenis karang (corals) atau $75 \%$ dari total spesies karang di dunia,Indonesia memiliki 30\% hutan mangrove dunia 13 spesies lamun (seagrass) dari 20 spesies lamun dunia, Indonesia memiliki berbagai potensi keragaman hayati laut lainnya seperti 35.000 spesies biota laut, 850 spesies sponges, 682 spesies rumput laut (seaweed), 2500 spesies moluska, 1502 spesies krustasea, 745 spesies ekinodermata, 6 spesies penyu, 29 spesies paus dan dolphin, 1 spesies dugong, dan lebih dari 2000 spesies ikan hidup, (Dahuri, 2003). Dari pendapat dan data tersebut bahwa wilayah perairan maupun laut Indonesia sangat potensial terjadinya kejahatankejahatan yang terjadi di laut.

Terjadinya gangguan yang terjadi di wilayah perairan atau wilayah yurisdiksi laut Indonesia yang paling utama yaitu terhadap gangguan pelayaran penumpang serta barang cukup tinggi. Di selat Malaka yang memiliki panjang area kurang lebih 900 $\mathrm{km}$ dengan lebar seluas $1,2 \mathrm{~km}$ menjadi salah satu jalur pelayaran yang paling padat di dunai. Pada saat ini setiap tahunnya terdapat kurang lebih 50 ribu kapal melintasi selat yang mengangkut sepertiga nilai perdagangan dunia dan setengah produksi minyak dan gas dunia, selain itu tindak kejahatan di wilayah perairan (piracy) seperti halnya tindak perampokan, dan penculikan, serta tindak kejahatan lainnya yang terjadi di selat Malaka merupakan yang paling tinggi di dunia apabila dibandingkan wilayah perairan lainnya. Berdasarkan data yang diperoleh pada bulan Febuari-Agustus 2010 di selat Malaka sedikitnya sudah terjadi lebih dari 16 kali terjadi perompakan terhadap beberapa kapal baik tanker kimia, kapal penarik, kapal pengangkut kapal tanker minyak, kapal serbaguna, dan kapal nelayan. (Didik Heru Purnomo,2014).

Terjadinya tindak kejahatan yang tinggi terjadi di wilayah perairan Indonesia memerlukan sistem keamanan maritim. Sitem keamanan maritim yaitu Sistem Pertahanan dan keamanan yang mencakup wilayah kedaulatan negara yang berada di perairan Indonesia dan juga kedaultan negara yang mencakup kapal nasional berbendera Indonesia yang berada di perairan Internasional maupun wilayah 
negara lain. Yang dapat melindungi kapal nasional dari penangkapan atau penahanan di luar wilayah Indonesia (Chandra Motik Yusuf, 5 : 2015). Kejahatan yang terjadi di peraira atau dilaut bisa menggunakan hukum pidana atau menggunakan hukum perdata tergantung kasus yang terjadi.Penulis membatasi tulisan ini terhadap hukum pidana yang terjadi di perairan atau laut.

\section{PEMBAHASAN}

Moeljatno mengartikan hukum pidana sebagai bagian dari keseluruhan hukum yang berlaku di suatu negara, yang mengadakan dasar-dasar dan aturan-aturan untuk :

1. Menentukan perbuatan-perbuatan mana yang tidak boleh dilakukan, yang dilarang, yang disertai ancaman atau sanksi pidana tertentu bagi siapa saja yang melanggarnya.

2. Menentukan kapan dan dalam hal apa kepada mereka yang telah melakukan larangan-larangan itu dapat dikenakan atau dijatuhi pidana sebagaimana yang telah diancamkan.

3. Menentukan dengan cara bagaimana pengenaan pidana itu dapat dilaksanakan apabila orang yang diduga telah melanggar ketentuan tersebut. (Moeljatno, 1: 2008).

Andi Hamzah mengatakan suatu kenyataan bahwa semakin hari semakin banyak delik-delik yang terpencar di luar KUHP hal ini karena disebabkan antara lain :

1. Adanya perobahan sosial secara cepat sehingga perobahanperobahan itu perlu disertai dan diikuti dengan peraturan-peraturan hukum pula dengan sanksi pidana. Hukum disini telah berfungsi sebagai "social engineering" maupun "social control".

2. Kehidupan modern semakin kompleks sehingga disamping adanya peraturan hukum (pidana) berupa unifikasi yang tahan lama diperlukan pula peraturan pidana yang bersifat temporer.

3. Pada banyak peraturan hukum berupa perundang-undangan di lapangan perdata, tata negara, dan terutama administrasi negara perlu dikaitkan dengan sanksi pidana untuk mengawasi peraturan-peraturan itu supaya ditaati.

Antara KUHP dengan delik-delik yang tersebar di luar KUHP itu ada titik pertalian. Titik pertalian itu terletak pada aturan umum Buku I KUHP. Hal ini jelas tercaantum dalam pasal 103 KUHP yang berbunyi sebagai berikut : "ketentuan-ketentuan dalam bab I sampai dengan bab VIII buku ini juga berlaku bagi perbuatan-perbuatan yang oleh ketentuan perundang-undangan 
lain diancam dengan pidana kecuali jika oleh undang-undang ditentukan lain." (Andi Hamzah, 9 : 1980).

Pengertian tindak pidana di laut adalah tindak pidana yang hanya bisa terjadi di laut saja dan tidak bisa terjadi di darat, dibedakan dengan tindak pidana umum yang terjadi di laut. Berawal dari pengertian tersebut maka timbullah akibatnya yaitu bahwa tindak pidana di laut menjadi suatu tindak pidana khusus yang mengandung arti bahwa tindak pidana di laut mempunyai kekhususan tersendiri. Kekhususan itu bisa terjadi meliputi seluruh unsur tindak pidana (subyek, kesalahan, bersifat melawan hukum, bertentangan dengan undang-undang, maupun unsur-unsur lainnya misal tempat, waktu dan keadaan lainnya). Karena merupakan tindak pidana khusus disebut juga delik khusus, delik tersebar, delik diluar KUHP, maka penyelesaiannya pun mempunyai kekhususan yang menyimpang dari tindak pidana umum (KUHP) sedangkan hukum acara juga ada penyimpangan dengan KUHAP bahkan aparat penegak hukum, hukum yang ditegakkan juga ada penyimpangan dan medianya juga lain yaitu berupa laut yang mempunyai sifat internasional sedangkan tata cara melakukan tindak pidana di laut pun berbeda karena menggunakan kapal, namun baik KUHP maupun KUHAP masih tetap melingkupi tindak pidana di laut. (Soepadi : 1-2, 2013).

Pengertian tindak pidana di laut menurut prosedur tetap penanganan (Protap) Tindak Pidana di laut oleh TNI $A L$, yang termasuk jenis-jenis tindak pidana di laut adalah :

1. Tindak Pidana Perompakan/ Pembajakan di Laut Perompakan/ pembajakan adalah setiap tindakan kekerasan/ perampasan atau penahanan yang tidak sah, atau setiap tindakan memusnahkan terhadap orang atau barang, yang dilakukan untuk tujuan pribadi oleh awak kapal atau penumpang dari suatu kapal.

2. Tindak Pidana Perikanan

Tindak pidana perikanan adalah tindak atau perbuatan penangkapan ikan yang melawan hukum sebagaimana diatur dan diancam dengan sanksi pidana oleh undangundang atau peraturan perikanan lainnya. Penangkapan ikan merupakan kegiatan yang bertujuan untuk memperoleh ikan di perairan yang tidak dalam keadaan dibudidayakan dengan atau cara apapun, termasuk kegiatan yang mengunakan kapal untuk memuat, mengangkut, menyimpan, 
mendinginkan, mengolah atau mengawetkannya.

3. Tindak Pidana Benda Berharga Asal Muatan Kapal yang Tenggelam di Dasar Laut (Benda Cagar Budaya/BCB)

BCB adalah benda yang mempunyai nilai sejarah budaya, ekonomi dan lainnya. BCB berasal dari muatan kapal yang tenggelam di perairan Indonesia dan telah berusia lebih dari 50 tahun. Pengangkatan adalah kegiatan yang meliputi penelitian, survei dan pengangkatan BCB. Pemanfaatan adalah kegiatan yang meliputi penjualan kepada pihak ketiga dan pemanfaatan lain untuk kepentingan pemerintah.

4. Tindak Pidana Lingkungan Hidup Tindak pidana lingkungan hidup adalah perusakan lingkungan dan pencemaran lingkungan baik yang disengaja maupun karena kealpaannya melakukan perbuatan yang mengakibatkan pencemaran dan/atau perusakan lingkungan hidup.

5. Tindak Pidana Pelayaran

Secara garis besar tindak pidana pelayaran adalah perbuatan pelanggaran terhadap segala sesuatu yang berkaitan dengan angkutan di perairan, ke pelabuhan,

dan keselamatannya, berdasarkan kualifikasi Undang-Undang Nomor 21 Tahun 1992 tentang Pelayaran, yang mencakup antara lain :

1) Pelanggaran terhadap sarana bantuan navigasi pelayaran dan fasilitas alur pelayaran (pasal 100);

2) Pelanggaran oleh nakhoda, terhadap tata cara pelayaran (pasal 101);

3) Pelanggaran berupa tidak menggunakan pandu di perairan wajib pandu dan melaksanakan pemanduan tidak memenuhi persyaratan (pasal 102);

4) Pelanggaran oleh nakhoda dan/atau pemilik kapal tentang pelaporan dan penyingkiran kerangka kapal (pasal 103);

5) Pelanggaran terhadap ketentuan pengoperasian pelabuhan umum dan khusus (pasal 104, 105, 106, 107);

6) Pelanggaran tentang perubahan kapal yang tidak dilaporkan kepada pejawab berwenang (pasal 108);

7) Pelanggaran terhadap daerah pelayaran dan kelaiklautan (pasal 109); 
8) Tidak mematuhi tata tertib lalu lintas kapal dan tanpa surat izin (pasal 110);

9) Pelanggaran terhadap persyaratan peti kemas (pasal 111);

10) Pelanggaran terhadap tanda pendaftaran kapal (pasal 112);

11)Pelanggaran berkenaan dengan pengalihan hak milik atas kapal tanpa nama (pasal 113);

12)Pelanggaran terhadap ketentuan pengibaran bendera kebangsaan (pasal 114);

13)Meninggalkan kapal tanpa alasan, secara paksa melayarkan kapal yang tidak laik laut dan menghalangi nakhoda kapal melaksanakan kewajibannya (pasal 115);

14)Pelanggaran terhadap tidak melaporkan buku harian kapal dengan ukuran tertentu kepada pejabat berwenang (pasal 116);

15)Pelanggaran berkaitan dengan ABK, seperti tanpa disijil, tanpa kemampuan dan tanpa dokumen pelaut, atau ABK tidak mentaati perintah nakhoda (pasal 117, 118);

16)Pelanggaran berupa pembuangan limbah/bahan lain dari kapal yang mengakibatkan pencemaran lingkungan hidup, dan tidak melakukan penanggulangan pencemaran dari kapalnya (pasal 119, 120);

17)Pelanggaran perizinan usaha dan kegiatan penunjang angkutan di perairan (pasal 121);

18)Pelanggaran terhadap kewajiban asuransi dan tanggung jawabnya terhadap pencemaran kapalnya, atau kewajiban asuransi atas usaha dan kegiatan penunjang angkutan di perairan (pasal 122);

19)Pelanggaran terhadap kewajiban pelaporan kecelakaan, pemberian pertolongan semampunya, dan tidak mencegah penyebarluasan berita kepada pihak lain (pasal 123); Pelanggaran terhadap kewajiban pemberian pertolongan semampunya terhadap orang di perairan dan di menara suar atau tubrukan dengan kapal lain (pasal 124 jo pasal 98 UNCLOS 1982);

20)Pelanggaran terhadap kewajiban melaporkan kecelakaan kapalnya atau kapal lain yang mengakibatkan kerusakan pada alur laut/bangunan di perairan yang membahayakan keselamatan (pasal 125);

21)Pelanggaran pengoperasian kapal/pesawat udara yang tidak 
membantu SAR, walaupun telah diberitahu secara patut oleh pejabat berwenang (126);

22) Pembuatan surat keterangan palsu oleh nakhoda dan $A B K$ atau orang lain selain nakhoda/ABK kapal Indonesia;

23) Pemakaian bendera Indonesia tanpa hak dan menyamar sebagai sekoci atau perahu kecil guna membantu orang sakit;

24)Melakukan pemngintaian tanpa izin;

25) Menggambar/memotret laut termasuk pantai tanpa izin;

26) Pengumpulan keterangan untuk kepentingan hankam tanpa izin;

27)Mengambang tanpa alasan yang sah.

6. Tindak Pidana Konservasi Sumber Daya Hayati dan Ekosistimnya

1) Kegiatan yang dapat mengakibatkan perubahan terhadap keutuhan kawasan suaka alam, yaitu :

a) Mengambil, menebang, memiliki, merusak, memusnahkan, memelihara, mengangkut dan memperniagakan tumbuhan yang dilindungi atau bagianbagiannya dalam keadaan hidup atau mati; b) Mengeluarkan atumbuhan yang dilindungi atau bagianbagiannya dalam keadaan hidup atau mati dari suatu tempat di Indonesia ke tempat lain di dalam atau di luar Indonesia.

2) Kegiatan yang terkait dengan pelanggaran terhadap satwa yang dilindungi atau terhadap bagian dari satwa tersebut seperti kulit, tubuh atau bagianbagian lain satwa yang dilindungi, ataupun barangbarang yang dibuat dari bagian satwa tersebut.

3) Kegiatan pelanggaran terhadap zona inti taman nasional, atau zona pemanfaatan dan zona lain dari taman nasional, taman hutan raya dan taman wisata alam.

\section{Tindak Pidana Kepabeanan}

Tindak pidana kepabeanan adalah pengangkutan barang yang keluar/masuk dalam negeri melalui laut tanpa dilindungi atau tidak sesuai dengan dokumen kepabeanan. Daerah pabean ini adalah wilayah $\mathrm{RI}$ yang meliputi darat, perairan dan ruang udara di atasnya, serta tempat-tempat tertentu di ZEE dan Landas 
Kontinen yang didalamnya berlaku undang-undang ini.

8. Tindak Pidana Kehutanan

Tindak pidana kehutanan adalah pengangkutan hasil hutan tanpa dilindungi dokumen yang sah, atau tidak melaksanakan pelelangan terhadap kekayaan negara berupa hasil hutan dan barang lainnya berupa temuan dan/atau rampasan dari hasil kejahatan atau pelanggaran dan tidak memberikan insentif dari hasil lelang kepada pihak-pihak terkait. Dalam hala ini perbuatan pelanggaran terhadapSurat Keterangan Sahnya Hasil Hutan (SKSHH), yaitu dokumen kehutanan yang harus melekat bersama-sama pada saat pengangkutan, penguasaan atau pemilikan hasil hutan karena SKSHH berfungsi sebagai bukti legalitasnya.

9. Tindak Pidana Keimigrasian

Tindak pidana keimigrasian adalah kedatangan atau kehadiran orang di wilayah RI dimana orang tersebut tidak terdaftar sebagai Warga Negara Indonesia dan tidak memiliki/dilindungi dengan dokumen keimigrasian.

10. Tindak Pidana Penambangan Pasir Laut
Tindak pidana penambangan pasir laut adalah kegiatan yang berhubungan dengan pengerukan, pengangkutan perdagangan dan ekspor pasir laut tanpa memiliki/dilindungi dokumen yang sah.

11. Tindak Pidana Pelanggaran wilayah (Tanpa Security Clearance)

Tindak pidana pelanggaran wilayah adalah tindakan kapal-kapal asing yang dengan sengaja berlayar atau mengambang untuk tujuan-tujuan tertentu yang mempunyai pengaruh terhadap segi keamanan dan/atau melalui daerah tertutup di daerah perairan Indonesia tanpa izin, kapalkapal asing tersebut meliputi kapal perang/militer asing, kapal ikan asing, kapal asing yang melakukan survei hidrografi, kapal asing dalam kegiatan eksploitasi/eksplorasi, kapal-kapal Yacht asing dan kapalkapal asing yang akan melalui daerah tertutup di wilayah RI.

12. Tindak Pidana Narkotika dan Psikotropika

Tindak pidana narkotika dalam bentuk pengangkutan narkotika adalah setiap kegiatan atau serangkaian kegiatan memindahkan narkotika dari satu tempat ke tempat lain dengan cara atau sarana angkutan apapun. 
Tindaka pidana psikotropika dalam bentuk pengankutan psikotropika adalah serangkaian kegiatan dalam rangka memindahkan psikotropika dari satu tempat ke tempat lain dengan cara moda, atau sarana angkut apapun dalam rangka produksi dan peredaran. Sedangkan transit adalah pengangkutan psikotropika di wilayah RI dengan atau tanpa berganti sarana angkutan antara dua negara lintas.

13. Tindak Pidana Senjata Api dan Bahan Peledak

Tindak pidana senjata api dan bahan peledak adalah perbuatan tanpa hak untuk memasukkan, membuat, menerima, mencoba memperoleh, menyerahkan atau mencoba menyerahkan, menguasai, membawa, mempunyai persediaan, menyimpan, mengangkut, menyembunyikan, mempergunakan atau mengeluarkan dari Indonesia sesuatu senjata api, amunisi atau bahan peledak.

14. Tindak Pidana di ZEE Indonesia Tindak pidana di ZEE Indonesia adalah perbuatan melawan hukum sebagaimana yang diatur dan diancam sesuai Undang-Undang Nomor 5 Tahun 1983 tentang ZEEI beserta peraturan pelaksanaan lainnya, yang meliputi (i) pembuatan dan/atau penggunaan pulau buatan atau instalasi atau bangunanbangunan lainnya di ZEEI tanpa izin atau tidak memenuhi syarat, (ii) eksplorasi dan/atau eksploitasi sumber daya alam atau kegiatankegiatan lainnya yang bernilai ekonomis tanpa izin atau tanpa persetujuan dengan pemerintah Rl, (iii) Kegiatan penelitian ilmiah di ZEEI tanpa persetujuan dari pemerintah RI, dan (iv) merusak atau memusnahkan dengan sengaja barang bukti yang digunakan untuk melakukan tindak pidana eksplorasi dan eksploitasi di ZEEl dengan maksud menghindari diri dari tindakan penyitaan terhadap barang bukti tersebut.

15. Tindak Pidana Terorisme

Tindak pidana terorisme adalah perbuatan yang dengan sengaja menggunakan kekerasan atau ancaman kekerasan menimbulkan suasana terror atau rasa takut terhadap orang secara meluas atau menimbulkan korban yang bersifat masal, dengan cara merampas kemerdekaan atau hilangnya nyawa dan harta benda orang lain, atau mengakibatkan kerusakkan atau kehancuran terhadap objek-objek vital yang strategis atau lingkungan hidup atau fasilitas publik atau 
fasilitas

internasional.

(www.tu.bphn.go.id, hal.25-33).

Apabila disimpulkan dari pendapat-pendapat tersebut menurut pendapat penulis tindak pidana di laut yaitu perbuatan melawan hukum terjadi diwilayah laut maupun diwilayah perairan yang memiliki karakter berbada-beda di setiap perbuatannya. Tindak pidana laut memiliki banyak sanksi pidana baik yang di atur dalam KUHP maupun Undang-undang di luar KUHP.

\section{KESIMPULAN}

Pengertian tindak pidana di laut adalah tindak pidana yang hanya bisa terjadi di laut saja dan tidak bisa terjadi di darat, dibedakan dengan tindak pidana umum yang terjadi di laut. Tindak pidana di laut terdiri dari Tindak Pidana Perompakan/Pembajakan di Laut, Tindak Pidana Perikanan, Tindak Pidana Benda Berharga Asal Muatan Kapal yang Tenggelam di Dasar Laut, Tindak Pidana Lingkungan Hidup, Tindak Pidana Pelayaran, Tindak Pidana Konservasi Sumber Daya Hayati dan Ekosistimnya, Tindak Pidana Kepabeanan, Tindak Pidana Kehutanan, Tindak Pidana Keimigrasian, Tindak Pidana Penambangan Pasir Laut, Tindak Pidana Pelanggaran wilayah (Tanpa Security Clearance), Tindak
Pidana Narkotika dan Psikotropika, Tindak Pidana Senjata Api dan Bahan Peledak, Tindak Pidana di ZEE Indonesia, Tindak Pidana Terorisme. tindak pidana di laut yaitu perbuat melwan hukum terjadi diwilayah laut maupun diwilayah perairan yang memiliki karakter berbada-beda di setiap perbuatannya.

\section{DAFTAR PUSTAKA}

Andi Hamzah, Delik-delik Tersebar Di Luar KUHP, Pradnya Paramita, 1992.

Chandra, Motik Yusuf, Lokakarya Kelautan Nasional 2015 : Mewujudkan Indonesia Sebagai Poros Maritim Dunia, Fakultas Hukum Universitas Padjadjaran.

Didik Heru Purnomo, Pengamanan Wilayah Laut, Jurnal Hukum Internasional, Desember, 2014.

Munsi Lampe, Seminar dan Lokakarya Kelautan Nasional 2015 : Memahami Kebudayaan Maritim Nusantara/Indonesia, Disampaikan Pada Acara Seminar dan Lokakarya Kelautan Nasional 2015 : Mewujudkan Indonesia Sebagai Poros Maritim Dunia, tanggal 9-10 Juni 2015 diselenggarakan oleh Universitas Padjadjaran Bandung.

Moeljatno, Asas-asas Hukum Pidana, Edisi Revisi, Rineka Cipta, 2008.

Noor Cahyo D. Aryanto Pengelolaan Sumber Daya Laut Sebagai Salah Satu Pilar Dalam Mewujudkan Indonesia Sebagai Poros Maritim Dunia Fakultas Hukum Universitas Padjadjaran Bandung 9-10 Juni 2015. 
Yudi N. Ihsan Menuju Indonesia sebagai Poros Maritim Lokakarya Kelautan Nasional 2015 Mewujudkan Indonesia Sebagai Poros Maritim Dunia Fakultas Hukum Universitas Padjadjaran Bandung 9-10 Juni 2015.

Zainal Arifin, Sumber Daya Laut Indonesia, Lokakarya Kelautan Nasional 2015 Mewujudkan Indonesia sbg Poros Maritim Dunia Fakultas Hukum Universitas Padjadjaran, Bandung 9-10 Juni 2015.

Internet :

http://fh.hangtuah.ac.id/index.php?optio $\mathrm{n}=$ com_content\&view=article\&id= 87:artikeltrialku\&catid=32:akadem ika\&ltemid $=47$

www.tu.bphn.go.id, hal. 25-33. 